IN brief

\section{Genentech grapples with direct offer}

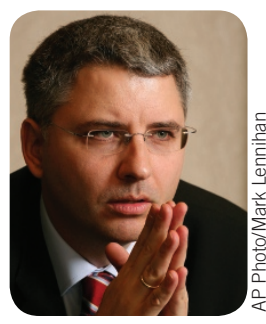

Severin Schwan, CEO of Roche, prays their low offer suceeds.

\section{Genentech}

shareholders have whether they want F. Hoffmann-La Roche at $\$ 86.50$ apiece following until midnight, EST, on 12 March to decide to sell their shares directly to Basel-based Roche's hostile cash tender offer, launched on 9 February. That's a drop in price from

July last year, when Roche proposed to buy Genentech for $\$ 89$ per share ( $\$ 43.7$ billion overall), giving Roche the $44 \%$ of Genentech shares it didn't already own. Closing the hostile bid is contingent on the majority of outstanding stakeholders tendering their shares to Roche, and on Roche securing the money for the deal-it says it will use its own cash reserves, commercial paper, bonds and 'traditional' bank financing to cover the cost. In response to the latest offer Genentech publicly asked shareholders to "take no action at this time." (Genentech in fact wants a much higher offer: filings by Roche with the Securities and Exchange Commission show that in a December meeting, representatives for Genentech indicated a willingness to pursue a transaction at $\$ 112$ per share.) If the offer is successful in winning Roche $90 \%$ or more of Genentech shares, it would then merge the companies. The failure to reach a conclusion on the original offer with Genentech, of S. San Francisco, is behind the hostile attempt, and the lower per-share offer reflects "the fact that a public purchase is a much more complicated transaction than a direct agreement with the board," says Severin Schwan, Roche CEO. But there is no shortage of theories as to why Roche made the move now, most interesting perhaps is the pending phase 3 data for Avastin (bevacizumab) as an adjuvant in colorectal cancer, due in April. A positive result there could build as much as \$15 into Genentech's stock, some analysts surmise, making Genentech prohibitively expensive. Others have pointed out that if the negotiations drag out further Roche might have trouble finding financing in what is universally described as a horrible environment for securing bank loans, especially as New York-based Pfizer recently announced it will purchase Madison, New Jersey-based Wyeth for $\$ 68$ billion, and would seek financing, too. Regardless, the tender offer has the industry buzzing (again) about Genentech's ability to retain its vaunted scientific talent with a future so cloudy. "I'm sure people are a bit unsettled," says the CEO of a southern California startup, who requested anonymity because he successfully recruited two ex-Genentech scientists to join his firm. "But people have been peeling off [from Genentech] from the beginning, for a whole variety of reasons. That's common to biotech anyway.

Brady Huggett
Moore has spoken with US policymakers about an oncology exclusion, but to no avail. "I'm concerned that we as a country are looking for a "one-size-fits-all answer," he says.

There is still hope that the bill will not be used to restrict access based on costs. At a January 27 Senate Finance Committee hearing, Wyoming senator Mike Enzi said he'd like to see the $\$ 1.1$ billion used to support "research on clinical effectiveness, not cost effectiveness" and that the bill should prohibit a comparative effectiveness infrastructure from "making any clinical guidelines or coverage decisions."

The outcome will set an important precedent, as the comparative effectiveness provision is among the first of several health-related policies and reforms to come this year. "It will set the tone for future bills," says DiMartino, "It would be really difficult to undo."

Questions around healthcare reform are in such a state of flux, says Ted Buckley, director of economic policy at BIO, that it is impossible to predict how it will all turn out. For the biopharma industry, the looming healthcare reform could present a mixed picture. In announcing GlaxoSmithKline's 2008 results, CEO Andrew Witty in February told analysts that the company sees both upsides and downsides to the coming healthcare reform. "On the downside, clearly there is discussion....around price levels and comparative effectiveness," he says. On the upside, President Barack Obama pushed for affordable healthcare coverage during his election campaign. Drug company executives hope to work with the new administration to expand coverage and reach new customers. Comparative effectiveness studies are nothing new, however. US public and private organizations have been conducting them for years, with varying objectives and criteria. Portland-based Oregon Health and Sciences University's Center for EvidenceBased Policy has been conducting literature reviews on drug classes since 2003 and has so far covered 34 topics. The project's subscribers - 14 states and Canada-choose the topics of the reports, which are produced at a cost of about \$60,000-180,000 each. "Most states use them to determine which [treatments] make their preferred drug lists [for Medicaid]," says Alison Little, medical director of the project, called the Drug Effectiveness Review Project, or DERP. The reports do not consider the costs of treatments, she says.
One of the advantages of such studies is that they have positive impacts on public health by providing information to doctors and patients. A year before New Jersey-based Merck withdrew the anti-inflammatory drug Vioxx (rofecoxib) from the market, DERP released a report highlighting the treatment's heart attack risk. As a result, several states, including Minnesota, Washington, Oregon and Montana, did not put the drug on their preferred drug lists. "The reports can be to industry's benefit when a product is shown to be very effective," adds Jean Slutsky, a director at the AHRQ.

Slutsky's agency, which is to receive $\$ 300$ million from the stimulus bill, has been publishing comparative effectiveness studies since 2005 after it was authorized to do so by the Medicare Prescription Drug, Improvement, and Modernization Act. Until now, the AHRQ's annual budget has been \$15-30 million, though the agency's spokespeople would not comment on how the additional funding from the stimulus bill might be used. In the past, the Medicare Modernization Act and the secretary of the HHS prioritized the disease areas that should be studied. Top priorities tended to be those "health care items" that "impose high costs on Medicare, Medicaid or SCHIP [State Children's Health Insurance Program]," for instance, cancer, diabetes and mental health. Right now, Slutsky says, AHRQ studies and reviews do not factor in costs, but use data from electronic medical records, registries and administrative claims data. She would not speculate on whether the stimulus bill might change that once it is implemented.

The lack of standard definitions complicates matters further. There is "no single correct way" to conduct such research, noted a 2007 white paper from BIO. With so many different kinds of groups conducting their own comparative effectiveness research, studies range in quality and aim to answer different questions. "Here is also where AHRQ or NIH could make the biggest impact: through a less biased assessment of what questions need answering most urgently," says Sebastian Schneeweiss, a pharmacoepidemiologist at Harvard University in Cambridge, Massachusetts.

How $\$ 1.1$ billion might change the comparative effectiveness research community is unclear. Says Little at Oregon Health and Sciences University: "This is more money than we've ever seen to do this kind of work in this country."

Emily Waltz New York 